\title{
DEVELOPMENT OF MIGRATION POTENTIAL IN HUNGARY FROM 2000 UNTIL TODAY
}

\author{
Margit Csipkés*, Sándor Nagy \\ Faculty of Economy Institute of Sectoral Economics and Methodology, University of \\ Debrecen, Debrecen, Hungary \\ csipkes.margit@econ.unideb.hu \\ nagy.sandor@econ.unideb.hu
}

\begin{abstract}
Hearing the words "international migration", two things might come to our mind. One of them is the emigration process and the other is the wave of refugees. In our study, we examined the changes of the number of employees emigrating from Hungary from 2000 until today. Nowadays, the examination of the migration potential is an important topic in Hungary, since the rate of Hungarian emigrants started to grow after 2006 and the rate of growth became even faster after 2010. The reason of the acceleration was the opening of the Austrian and German labour market. The actuality of the topic is based on the fact that international emigration merges the labour market's processes, influences the given country's employment level, moreover it has an influencing role on the rate of wages. Emigration from a given state has several reasons: natural disasters, war, marginalization, economic reasons, etc. In our study, we examine emigration caused by economic reasons. We have to take into consideration that measuring emigration processes is a difficult task, due to the lack of data. The reason of the deficiency is that those who leave the country, often forget to report their leaving. From 1 March 2013, only the permanent foreign settlement should be reported towards the administration (District Office, Consulate). Earlier, temporary (more than 3 months) settlement was also obligatory to be reported. Many of the leaving Hungarians do not report their leaving, however working abroad for more than 3 months should be reported towards social insurance organizations and tax authorities. I would like to emphasise that my migration potential presentation does not show a direct correlation with the actual migration. However, this study might show the expected movement rates and the composition of emigrants.
\end{abstract}

Keywords: migration, migration potential, Hungary, emigration

JEL classification: R23, O15, J61

\section{Introduction}

Hearing the words "international migration", two things might come to our mind. One of them is the emigration process and the other is the wave of refugees. In our study, we examined the changes of the number of employees emigrating from Hungary from 2000 until today. Nowadays, the examination of the migration potential is an important topic in Hungary, since the rate of Hungarian emigrants started to grow after 2006 and the rate of growth became even faster after 2010. The reasons of the acceleration were the opening of the Austrian and German labour market and the fact that however the number of the population and the number of the working age population have risen, the economic growth could not keep pace with it, could not provide enough workplaces.

At first, people changed their homes within a given country; many of them moved to towns, looking for better opportunities. Later, it was not enough and people started to leave their motherland and find work abroad.

\footnotetext{
* Corresponding author: Margit Csipkés
} 
International migration affects the given foreign country in several ways, for example it merges into its labour market processes, influences its employment level as well as its wages. Emigration has many causes, like natural disasters, war, exile, economic causes, etc. In our study, we examine emigration caused by economic reasons. Measuring emigration processes is a difficult task, due to the lack of data. The reason of the deficiency is that those who leave the country, often forget to report their intention of leaving. From 1 March 2013, only the permanent foreign settlement should be reported towards the administration (District Office, Consulate). Earlier, temporary (more than 3 months) settlement was also obligatory to be reported.

I would like to emphasise that my migration potential presentation does not show a direct correlation with the actual migration. However, this study might show the expected movement rates and the composition of emigrants.

\section{Method}

I was examining one particular segment of international migration, so at first, I would like to explain the notion of emigration. Emigration can be divided into two groups: permanent and temporary. Permanent emigrants leave their country for good, they settle down abroad and the chance of returning home is minimal. In this case, residence exceeds 12 months. It is different in almost every country, for example in Italy and Belgium even 3 months is considered critical, while in the Netherlands, 6 months is accepted.

The other group of emigrants are the temporary emigrants. Unlike the permanent emigrants, they keep up the chance to return home. Those people are also in this group who are part of a foreign household, they are called commuters (Table 1).

Table 1: Types of international emigration and database connected to them

\begin{tabular}{|c|c|c|}
\hline \multicolumn{3}{|c|}{ Emigration } \\
\hline permanent & \multicolumn{2}{|c|}{ temporary } \\
\hline does not plan to return & $\begin{array}{c}\text { comes with } \\
\text { moving }\end{array}$ & commuting \\
\hline $\begin{array}{c}\text { Based on the database of host countries } \\
\text { (Immigration, Statistical Office, etc.) }\end{array}$ & $\begin{array}{c}\text { National labour } \\
\text { research (MEF) }\end{array}$ \\
\hline
\end{tabular}

Source: Own editing

Unconventionally, there are certain overlaps among the groups, as in the case of recording statistical data, a person can be considered an individual migrant, although in most cases migrants travel to the destination country with their whole family. For the interpretation of the categories, another important aspect is that there is no exact definition of the expression "migrant".

Another classification should be mentioned, since there is a difference between temporary and permanent migration. Those people who stay less than 3 months (because of visa commitment) in the destination country are regarded as visitors. The second group involves short-term migrants, who move from their temporary habitation to another country and stay there for more than 3 but less than 12 months, except for those people who are travelling for medical treatment, to visit their doctors, their family or going on holiday. The third category involves long-term migrants, those people who stay in the destination country for more than 12 months (Figure 1). 


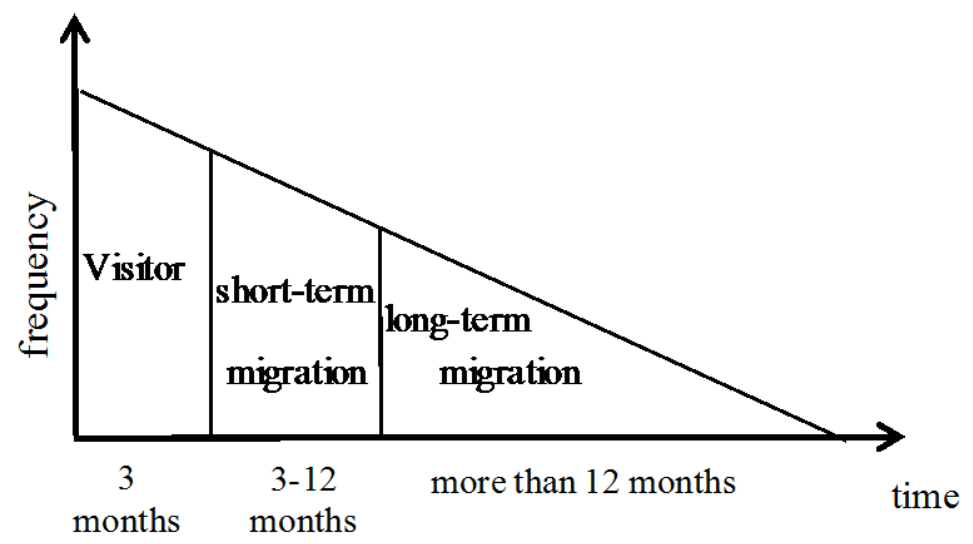

Figure 1: The migration period grouping

Source: Own editing based on Boden and Rees (2008) data

After reviewing the time periods, it can be useful to examine the reasons of migration. There are voluntary and forced migrations. In the case of voluntary migration, migrants leave their countries because of economic reasons. Contrary to voluntary migration, there can be some persecuting act behind forced migration regarding religion, politics, ethnics, language, nationality etc.

Based on the different types of emigrants, the database can be found at different places. There is no official database for permanent emigration, since host countries do not make statistics from them. There are a very few information in the host countries (they provide information in different sections with different frequencies) about the number of Hungarian residents there, thus, the overall number of people cannot be collected in this way.

According to Mirror Statistics, the movement of migration is limited to the temporary/commuting type, based on the reported information. About the temporary emigrants, we are informed from different labour market researches. According to the World Bank (2011), 462 thousand Hungarian (nearly 5\% of the population) moved to a foreign country, from whom 400 thousand settled down in one of the OECD countries (OECD, 2011). This $85-87 \%$ OECD rate is true for each of the past years.

According to the data of the Mirror Statistics (2014), those Hungarian people, approximately 330 thousand, who live in a European country, are younger and more qualified than the national average. In 2014, Germany, Ireland and the United Kingdom were targeted mostly by men, while Italy, Austria, Switzerland and Spain were targeted by mostly women (KSH, 2015).

According to the data (2015) of member states of the EU, the number of Hungarian citizens were 310 thousand in European countries; this number has increased by 48 thousand in the previous year. From the 370 thousand, $41 \%$ went to Germany, 23\% to the United Kingdom and $15 \%$ to Austria. According to the data, by the end of 2015 , the attractiveness of Germany decreased compared to the previous years; however, the UK has become a more popular destination. In 2016, the Netherlands, Ireland and Denmark (which were insignificant before) became new emigrational targets.

In opposition, relevant literatures mention approximately $1-2 \%$ of Hungarians who live in a foreign country (Blaskó, Ligeti and Sik, 2014; 2011. census; Blaskó and Gödri, 2016). According to mirror statistics, the emigrants staying abroad have a 3-4\% rate. One of Hárs' research (2016) examined the member states of the European Union and it concluded the actual situation considering Hungary as well. According to Hárs' opinion, the emigration rate of Hungarians is 3\% and only the Czech, the Slovakian and the Slovenian figures are lower. The constantly changing number of commuters is not recorded in Hungary, hence it would be hard to keep count of them from time to time. It would be possible to gain some 
information about commuters; however, there is no data of those people who live in a one-man Hungarian household but work abroad. Information on commuters could be gained from Labour researches that say that by the end of 2013, there were 100 thousand commuters (work on a foreign site but registered in a domestic household and the income is present in Hungarian households.).

Obviously, there are overlaps among the groups constantly, and the given data could provide approximate information about the number of members in each group.

According to Dustmann and Weiss (2007), emigration with the purpose of working abroad can be considered temporary, since the goal of these emigrants is to gain experience, besides, usually they have a contract that limits their staying. In many cases, temporary emigration ends completely, if the emigrant comes back to Hungary or if he/she stays for a longer period in the given foreign country.

It is also crucial to understand and to examine the advantages of being a host country. Receiving immigrants could be an advantage for the destination country, if they boost the labour market there. In the case of economic migrants, the qualification of the person is the responsibility of the origin country, so it is beneficial for the host country. Receiving people with extra qualifications and expertise means technological-economic development for the destination country. Another perspective is that economic migrants can have a positive effect on the budget of the destination country: if workers arrive to a country legally, the taxes and social contributions of their income will be paid to the central budget. Since these people live in the country, they will consume there and this is another positive effect. The next significant advantage of immigrants is that they could fill in the blanks in skill shortages.

The migration process also has negative and positive effects on the origin country. Emigration causes a decrease in the number of active population, so as a result, unemployment and social tension will also decrease. Huzdik (2014) also conducted surveys on this topic. His research shows that emigrants support their family staying in the origin country financially (so family members are not inspired to work), which makes the expenses of the social service system decrease. Another positive aspect for the mother country is that the salaries sent home from abroad improves the balance of payments by which reverse currency can be created. Its disadvantage is that migration means tax shortfall for the origin country in the short-term as well as in the long-term, although it could result in increasing life standards for migrants. Another disadvantage for the future is that when a family emigrates, it reduces the number of working-age citizens, which cuts down the economic growth. This is the reason why it would be crucial for the countries to make their citizens stay at home, motivate them and make their own country attractive, so that they would not even think about the possibility of moving abroad.

The return of migrants is beneficial if they come back to their own country with certain advantages. After returning home, the acquired knowledge can be developed, however it is not guaranteed that this knowledge could be applied in their original profession. The return could be a disadvantage if the person uses the earned money to develop his/her life standards (it could lead to certain social tensions).

In conclusion, migration is "good" for the origin country, as it makes easier to make connections with other countries, it increases the incoming working capital (new workplaces can be established), increases the number of qualified people (which is not obtained at the cost of the country), and innovation also increases competitiveness (side by side, disbursement used for unemployment problems could be reduced).

From the aspect of the destination country, migration's positive effect is that highly qualified workers start to work in the country (with which, the Research + Development activity could be intensified), more enterprises can be established (the unemployment rate could be reduced), immigrants could increase creativity, qualified migrants could rise the number of successfully launched programs, and the supply services of personnel could be more efficient if immigrants do well on the labour market. 
According to Borjas (1994), migrants' work is highly productive, they can also adapt easily to the labour market of the destination country, which contributes to the economic growth of the destination country.

\section{Beginning of migration in the European Union}

Based on the data of the relevant literature, it can be stated that the migration wave has a long history in the member states of the European Union. The history of the European migration has five periods (Table 2):

Table 2: Historical periods of migration from 1945 until now in Europe

\begin{tabular}{|l|l|l|}
\hline \multicolumn{1}{|c|}{ Periods } & \multicolumn{1}{|c|}{$\begin{array}{c}\text { Migration } \\
\text { tendencies }\end{array}$} & \multicolumn{1}{|c|}{ Migration trends } \\
\hline $1945-1973$ & $\begin{array}{l}\text { Economic } \\
\text { immigration }\end{array}$ & $\begin{array}{l}\text { North-Western Europe from } \\
\text { South to East }\end{array}$ \\
\hline $1973-1988$ & Family union & $\begin{array}{l}\text { The whole Western Europe, } \\
\text { opposite trends }\end{array}$ \\
\hline $1988-1998$ & $\begin{array}{l}\text { Refugees, } \\
\text { asylum-seekers }\end{array}$ & $\begin{array}{l}\text { The whole Western-Europe, } \\
\text { from East to West }\end{array}$ \\
\hline $1998-2008$ & $\begin{array}{l}\text { Controlled } \\
\text { migration }\end{array}$ & $\begin{array}{l}\text { The European Union from East } \\
\text { to South }\end{array}$ \\
\hline $2008-$ present & $\begin{array}{l}\text { Migration } \\
\text { potential }\end{array}$ & $\begin{array}{l}\text { The centre of the European } \\
\text { Union }\end{array}$ \\
\hline
\end{tabular}

Source: Personal edition based on the data of Koller (2011)

Each period involves a migration wave that was caused by a certain event. The first period is the second part of the 1940s, when people started to migrate because of World War II (because of the shortage of labour). One part of this period's immigrants was the minority arriving from the nearby countries, while the other part includes those people who had moved from their locations and then returned. Based on the study of Huzdik (2014), the number of migrants in central Eastern Europe is approximately 25 million.

Another important date of this period is the European Integration (1957), which substantially determined the number of emigrants and immigrants of the countries. The essence of the Integration is the free movement of capital, labour force, products and services among the member states (at the same time, this is the principle of the four freedoms). European Integration has helped to open the country borders for the emigrants.

The second period consists of the 1970s and 1980s and it relates to the migration wave from the countries of the third world.

According to Cseresnyés (2005), this period was a migration of several layers of society, since the officers of independent colonies (white-collar workers) returned to their homeland (the Netherlands, Belgium, France and Great Britain) and a part of the population of the colonies followed them as former employees to their mother countries. The main trends based on the descriptions: workers arrived to the United Kingdom from Pakistan and India, whereas to Portugal mostly from the areas of Angola.

The 1970 s and 80 s was also the period of the migration of guest workers, since certain industrial countries of Western Europe recruited people from the Mediterranean countries. The recruitment of the 70s worked for several years but after the two oil crises of the 1970s that led to recession, unemployment increased. The reaction of the countries of European Community was that the immigration of labour force was prohibited; after that, guest workers started to settle down in the given country, so they became immigrants.

The third period involves the 1980s. During these years, the Eastern-Western migration flow became more intense; new opportunities emerged for the migrants. 
The Maastricht Treaty of 1990 was a huge progress, it developed integration even more. Later, the Schengen Area was established, which meant that there was no need to have a passport to cross the borders, an identity card was enough to go through security checking. These factors boosted migration across the given countries.

At the beginning of the 1990s and 2000s, there was a significant increase of migration in the following countries: Italy, Portugal, Spain, Austria, Ireland and the United Kingdom. Based on several researches, approximately 22 million foreigners lived in Europe in 2000.

The results of 2006 are also significant; from the member states of EU15, Polish, Lithuanian, Estonian and Slovakian workers were employed in the member states of EU15 (particularly in Ireland and in the United Kingdom). Based on several studies, mostly the young people (between the ages of 18 and 30 ) with secondary education moved to a foreign country.

Far away from their mother country, these people were willing to do jobs different from their qualifications. An explanation of this phenomena could be that in their mother country, in the absence of the possibility of employment, they could not see any options to develop their life standards.

The last period started in 2008 and it is currently going on. The willingness to emigrate and immigrate is still present. One of the characteristic features of this period is the emigration of young people, between the ages of 18 and 25 . The emigration of youngsters makes the society of the destination country younger. The four most significant destination countries are Spain, Germany, the United Kingdom and Italy. More than 2/3 of immigrants of the EU were moving to these four countries. The biggest number of immigrants moved from Germany in 2008, which caused a negative migration in the country. Romania, Poland and Bulgaria (plus 3 Baltic States) can also be rated as countries of negative migration (i.e. less immigrants than emigrants).

\section{The beginning of working emigration in Hungary}

In a European Union comparison, since the change of regime (approx. 1990), Hungary belongs to the countries that have a low but positive international emigrant balance. The growth rate of emigration accelerated in the past few years. Working abroad has already started in 2004, however significant changes came after 2008. One of the main reasons of that is from 2008, the rate of unemployment started to increase in Hungary. In the majority of the host countries, the rate of unemployment was lower than in Hungary (in Ireland, 4,5\% at the beginning, later 6\%, Germany approx. 6\%, United Kingdom approx. 4,5-6\%). For emigrants, low unemployment rate and high chances of job-finding could be positive (Figure 2).

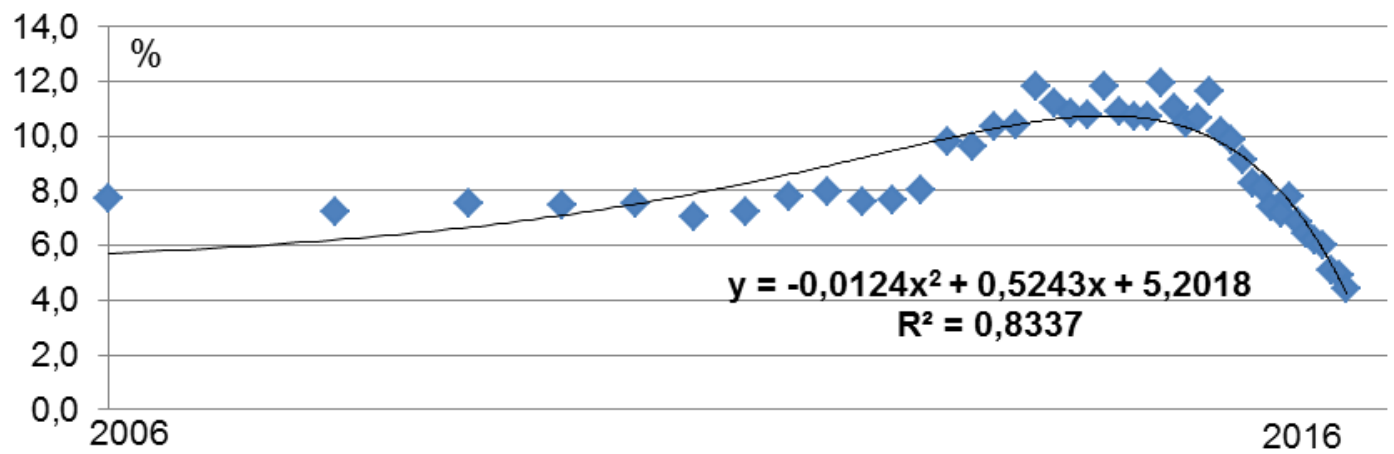

Figure 2: Unemployment rate in Hungary between 2006-2015

Source: Own calculation based on the database of KSH (2017)

The other main feature that can be attractive for emigrants is the differences between the incomes of the origin and the host country. However, it must be emphasized that the foreign 
salaries should be much higher, since the moving/commuting and the costs of integration should also be financed from the foreign salary. Besides these, the social supply system, the development of educational system and the general political mood in the host countries could be attractive.

Employees, who count as migrants, emigrating abroad are called economic migrants by the literature. In the past few years, the most important destination countries from Hungary were Austria, Germany and Great Britain (TÁRKI, 2016; Galgóczi and Leschke, 2012). As it is shown on Figure 3, the total gross of the three dominant countries decreased throughout the years of 2010-2015, which means that it is not necessarily the neighbouring countries of Hungary that are visited by potential migrants. Furthermore, Figure 3 also shows that the United Kingdom, which is considered the country of emigration and long-term work, became less significant compared to Austria and Germany.

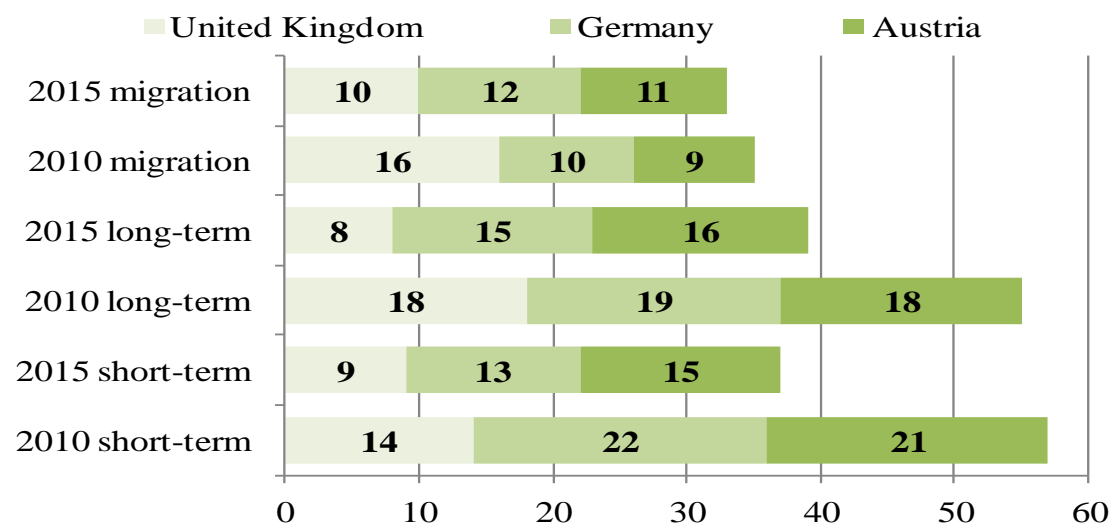

Figure 3: Trend of migration percent in the period of planned migration (in 2010 and 2015) Source: Own calculation based on the database of TÁRKI (2017)

According to the researches of Hárs and Simon (2015), Austria is a destination for migrants with secondary educational degrees, Germany for skilled workers and the UK is a destination country for those who have higher educational degrees or who are overqualified. Another significant coherence is that those people who decides to go to live in Austria or Germany are coming from a family consisting of 5-6 people, while those who are going to Great Britain are coming from a much smaller family, that has 1 or 2 members in one household.

One of the main reasons of emigration is that foreign workplaces provide a higher salary for skilled workers; as a result, skill shortages emerged in Hungary in 2015. At the beginning of the 1990s, economists said that the lack of checking the borders would led to a powerful migration pressure (Layard et al., 1992).

Another reason of work emigration is that with the change of regime, country borders became accessible and it let the international migration process increase (emigration and immigration).

Examining the data of the last 10-15 years, emigration has a minimal significance before the 2000s in Hungary; Hungarian citizens did not intend to move to foreign countries. Nowadays, this rate has changed, the number of those who are willing to move aboard has risen.

After the start of the crisis, unemployment has increased in Hungary and it encouraged the willingness to move abroad. The emigration of Hungarians (especially for a working purpose) started in 2007 and it became more powerful in 2011. From 2013, the intensity of the process decreased a little. 


\section{Migration potential in Hungary}

Before discussing the timeline, it is important to define what migration potential actually means. The notion 'migration potential' shows the percentage of those people who are intended to work in a foreign country and it also shows the number of those who have the intention of emigration.

Detailed analyses of the migration processes are impeded by the limited number of available data. In our calculations, we have gathered data in a special way.

Some parts of the calculations are based on the number of visitors available in host countries, while in other parts we took the number of Hungarian emigrants into consideration from mirror statistics. Mirror statistics creates a matrix from the number of those who moved to developed countries of the European Union and live there for more than one year. In case of missing data, we used the database of EUROSTAT. Because of the lack of relevant data, we cannot draw any conclusions concerning the future; drawing any conclusions would require high professional knowledge.

The period between 1993 and 2016 (Figure 4.) shows that the initial, low percentage of emigration (8\%) doubled for 2001 (19\%), and it almost tripled for 2005 (22\%). The highest rate of migration potential was in $2012(36 \%)$ which decreased to $27 \%$ in 2016 . According to the data of the last 10 years, short-term and long-term employment have the same magnitude, while emigration has smaller proportion.
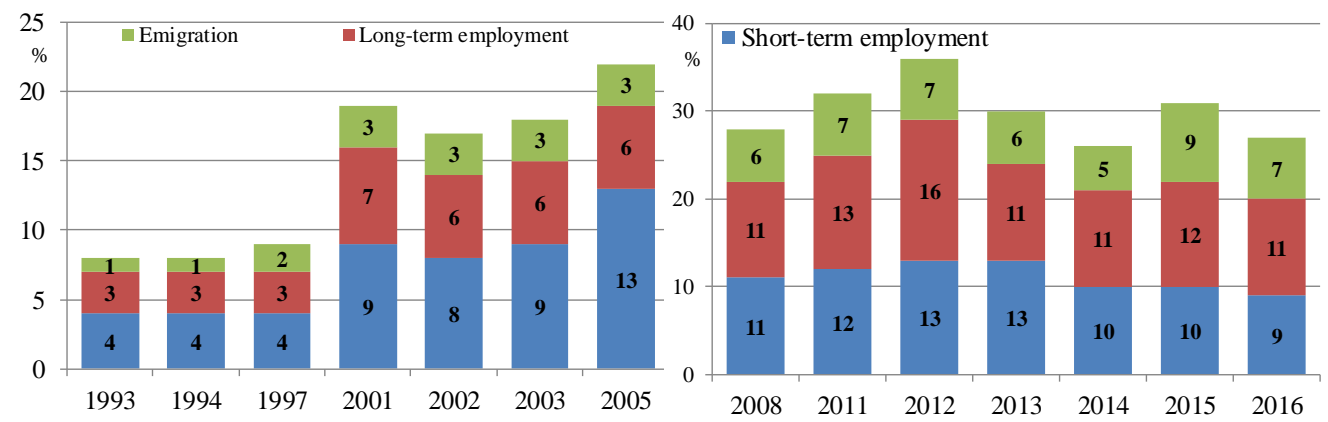

Figure 4: Migration potential of the Hungarian population between 1993 and 2016 Source: Own editing based on the data of Sik and Szeitl (2016)

Examining the composition of short-term emigrants, it can be stated that the vast majority of emigrants are young people; the number of older people is insignificant.

$71 \%$ percent of Hungarian emigrants are up to the age of 45 , from which $12 \%$ are between the ages of 16 and 25 and $26 \%$ are between the ages of $26-35$.

In the total amount of emigration, both for short-term and for long-term, young people, those who are under the age of 30 , give a $44 \%$ majority. It is also an interesting fact that $71 \%$ of Hungarian emigrants are under 45 (Figure 5).

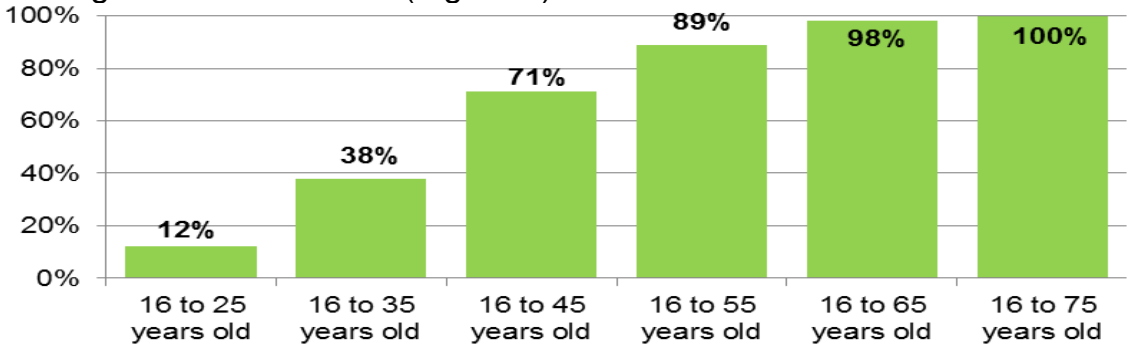

Figure 5: Developments in the Hungarian population's migration potential in 2016 Source: Own calculation based on the database of TÁRKI 
Usually, migration potential emerges in those people who are intended to develop their life standards in the future. Those Hungarian citizens, who already own a flat/house and have already achieved high living standards, generally do not wish to live and work abroad.

As for territorial distribution, citizens from Budapest, West Dunántúl and Eastern Hungary are the most likely to leave for a short time. Long-term working in abroad is not necessarily originates in economic reasons, but in family statuses or in lower levels of education.

Compared to other member states of the European Union, Hungarian migration started a little later. After the economic crisis, besides Hungary, people from Romania, Bulgaria and from the Baltic countries, which have a high rate of unemployment, begin to migrate in greater numbers.

Regarding the migration willingness of the member states of the EU, it can be concluded that in 2009, the migration potential of Hungary (29\%) was above the EU 's average (17\%) (Figure 6). The highest migration willingness was typical of Denmark (51\%) and of Estonia, Sweden, Latvia and Lithuania (35-36\%). Hungary is in the middle with its $29 \%$ rate besides Slovakia, the United Kingdom and France. Bulgaria, Romania, Spain, Germany and the Czech Republic are below the average of the European Union.

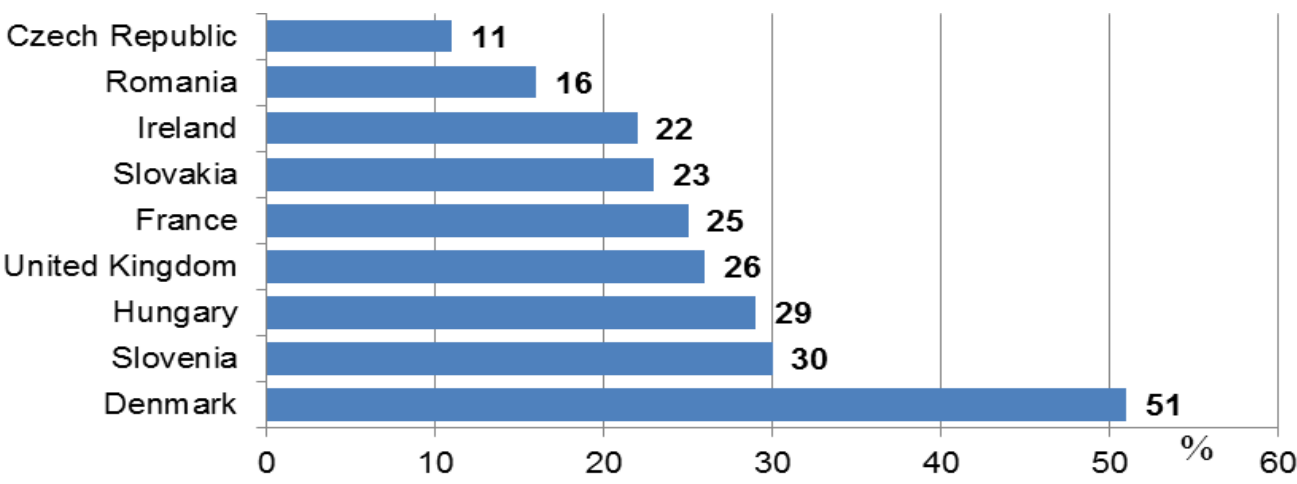

Figure 6: Migration potential in the member states of the European Union Source: Own editing based on Special B. (2010)

\section{Emigration's effects on the economy}

We met a number of studies when processing literature and materials, but one of the best ides was of British economist Paul Collier, a former development director at the World Bank and professor of the University of Oxford. According to him, despite the rapid transformation of our societies caused by migration, the scientific examination of the issue is currently limited to the positive effects of the phenomenon.

According to Coller's writings, we can say that mass immigration has the greatest impact on host countries, which primarily means a social cost. According to the researcher, the advantage of Western civilization, comparing to the developing countries, can be the success of political and social institutions. Institutions, rules and norms are the most important fundamentals of a society, and for these it is always appropriate to develop a certain social model. Of course, this social model is different in every country, but each model has the same purpose: creating a proper social structure.

However, in addition to social impacts, the economic effects of immigration are more important, since if we only consider that the real wages of a given country are reduced due to immigration, then large changes can be observed in the economic structure. When real wages are reduced, it means that immigrants are willing to do the same job for less money, 
and this fact increases the income of their employing companies. It means that immigrants have a very good effect on companies, while they mean a risk to local workers. This is true for workers emigrating from Hungary to different countries, but on the basis of surveys, we can say that it is true for workers who earn less money.

\section{Effects of migration in Hungary}

Migration can have political and economic effects on Hungary, which later can have serious political benefits for the country. Students going abroad and workers returning to Hungary can have a great influence on the political development of the country. This theory is supported by a foreign survey carried out in Mali and Moldova. This study also demonstrates that those who return to the home country from abroad tend to take part in different elections more actively, and they vote more, but naturally the effects of migration are country-specific. When talking about migration, we can conclude that there is a serious economic impact on the so-called "brain drain" phenomenon in Hungary. It is a proven fact that more talented people tend to move abroad. This is also supported by the fact that recently in Hungary, there has been a serious shortage of professionals in hospitals, since skilled workforce (university students) has emigrated from the country, and this causes serious economic disadvantages in Hungary.

\section{Examining the number of emigrants based on different parameters}

The databases of our surveys were provided by the Labour Force Survey of Hungary, and they cover a large number of outgoing travellers. In our study, we are going to examine the age group, qualifications and residence analyzes.

Firstly, it was important to compare commuters and local workers in Hungary as differences can already be found here (Table 3.)

Table 3: Comparison of domestic workers and emigrants based on indicators:

\begin{tabular}{|l|c|c|c|c|}
\hline \multirow{2}{*}{ Denomination } & \multicolumn{2}{|c|}{ 2004-2007 } & \multicolumn{2}{c|}{ 2008-2016 } \\
\cline { 2 - 5 } & $\begin{array}{c}\text { Domestic } \\
\text { worker }\end{array}$ & $\begin{array}{c}\text { Emigrant, } \\
\text { commuter }\end{array}$ & $\begin{array}{c}\text { Domestic } \\
\text { worker }\end{array}$ & $\begin{array}{c}\text { Emigrant, } \\
\text { commuter }\end{array}$ \\
\hline Average age (years) & 39,7 & 38,2 & 41,8 & 36,1 \\
\hline $\begin{array}{l}\text { Rate of women in the active } \\
\text { population (\%) }\end{array}$ & 45,8 & 23,4 & 47,2 & 26,4 \\
\hline $\begin{array}{l}\text { The proportion of workers with } \\
\text { primary education in the active } \\
\text { population (\%) }\end{array}$ & 14,8 & 5,6 & 11,9 & 9,4 \\
\hline $\begin{array}{l}\text { The proportion of skilled } \\
\text { workers with secondary school } \\
\text { education in the active } \\
\text { population (\%) }\end{array}$ & 56,1 & 70,2 & 52,1 & 64,1 \\
\hline $\begin{array}{l}\text { The proportion of workers } \\
\text { without a secondary school } \\
\text { education in the active } \\
\text { population (\%) }\end{array}$ & 8,8 & 5,4 & 9,9 & 9,7 \\
\hline $\begin{array}{l}\text { The proportion of workers with } \\
\text { high-level education in the } \\
\text { active population (\%) }\end{array}$ & 20,3 & 18,7 & 22,7 & 28,1 \\
\hline
\end{tabular}

Source: Own calculation based on the database of KSH (2018) 
Table 3 shows that the average age of Hungarians emigrating from Hungary has decreased from 38 to 36 years, which means that younger people are going abroad. Compared to employees remaining in Hungary, it can be stated that while between 2004 and 2007 the average age difference was only 2 years, between 2008 and 2016 this number raised to 4 . When examining the gender ratio, it can be seen that while $46 \%$ of working people in Hungary are women and only 23\% of the emigrants were women between 2004 and 2007. These rates increased in both categories between 2008 and 2016, as the proportion of women working in Hungary in the active population is $47 \%$, while the proportion of women among the emigrants is $26 \%$.

We have also completed qualification studies to establish that the proportion of primary school graduates decreased in Hungary, while the number of workers with secondary (vocational or non-vocational) and high-level education increased. The proportion of non-qualified emigrants with primary, secondary or high-level education has increased. The greatest increase can be seen among graduates with high-level education which can be explained by the growing number of young graduates working abroad.

From our data it can be stated that nearly two-thirds of commuters/emigrants have at least a vocational qualification. In many cases it is typical that people travelling abroad from Hungary have a job that requires less qualification than they have. Among the emigrants there are many who do physical work. These jobs are typically in the commercial or service sectors, and in many cases these jobs do not require professional skills, they can be carried out by unqualified physical strength. This is why these jobs are attractive for young, unskilled Hungarian people. However, it is very rare among the respondents to make some professional progress abroad.

In the following, we would like to present the age group analysis. We used for the calculation the officially available Labour Force Survey data. From our calculation it can be seen that in comparison with the year of 2004 , by 2013 a significant increase can be seen in all age groups. The highest growth rate was between 31 and 39 which suggest that after graduation many young people think that they would rather emigrate from Hungary for better circumstances.

All in all, we can say that emigrants are between the age of 25 and 40 with the highest proportion of people between 25 and 35 (Figure 7).

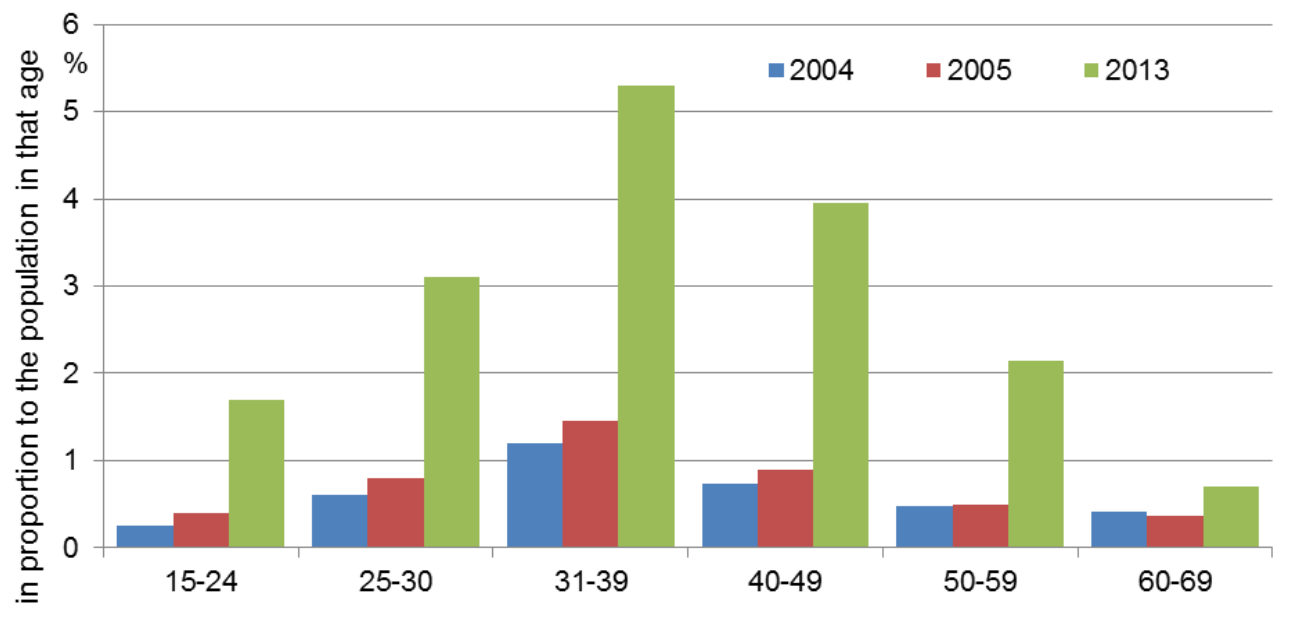

Figure 7: Age group survey of emigrants from Hungary

Source: Own calculation based on the database of KSH (2018) 


\section{Emigration's effects on Hungary}

Emigration in Hungary (and in all sending countries) means a risk for the size and composition of the population. Of course, there are changes in the proportion of education, experience, age, productivity and consumer behaviour. It has a negative effect on the size a structure of available workforce, average productivity, aggregate consumption, savings and this way on budgetary payments and transfers. On the other hand, emigration may change the behaviour of the non-migrant population and companies. Naturally, effects appear differently in composition and time.

Of course, emigration has both positive and negative effects on Hungary. Positive effects are the followings:

$\checkmark$ lower social spending in the country;

$\checkmark$ if underprivileged (unemployed and uneducated) workers are leaving the country, then the average productivity of Hungary is increasing ;

$\checkmark$ if they leave jobs that are over-supplied in Hungary, then fitting problems can be solved;

$\checkmark \quad$ sending money back to the family members in Hungary can increase domestic living standards, more resources can be used in education and investments;

$\checkmark$ foreign work experience can be used in Hungary, and it can be transferred to the domestic workforce;

$\checkmark$ the relationship regarding trade between the two countries is developing.

Of course, there are negative effects too that Hungary has to face because of emigration:

$\checkmark \quad$ with the emigration of young people the average age in Hungary is growing,

$\checkmark$ some areas may be aging because of the emigration;

$\checkmark$ the sustainability of social welfare system is in danger (healthcare, pension system);

$\checkmark$ if university graduates go abroad, then average productivity is decreasing in the country;

$\checkmark$ "brain drain" by foreign companies;

$\checkmark$ decreasing tax revenues;

$\checkmark$ number of founding families is declining in Hungary.

Naturally, when examining the impacts, individual macroeconomic indicators should be taken into consideration. In our calculations we analysed the following indicators:

$\checkmark$ Rate of unemployment and rate of activity: since emigration reduces the available workforce on the farms, job opportunities of non-emigrant people are increasing. This can positively influence activity in those groups where inactivity is due to bad employment opportunities. This means that without emigration the unemployment rate would be higher and the activity rate would be lower. This effect may be moderate if emigration causes adaptation problems in the labour market i.e. the knowledge and experience of emigrants cannot be replaced on the domestic market.

$\checkmark$ Savings: emigration of employees with higher productivity and higher earnings can substantially reduce the aggregate savings. This can be balanced by sending money back to the home country by emigrants. Remittances of long-term emigrants may be under the level of savings they would have accumulated in domestic employment.

$\checkmark$ Sustainability of supply systems: emigration of the young population can deepen the problems of aging societies. The number of payments for the social health care and the size of average payments can also be reduced, while the size of the retired population is increasing. To sum up, sustainability of care systems becomes more risky. This means a relatively high risk in Hungary as the number of active people is declining which is caused by emigration too.

$\checkmark$ Effects on the budget: due to the lower unemployment and the higher activity rates social spending can be reduced. However, the emigration of highly-skilled and well-paid workers has a negative effect on tax revenues and on the balance of the 
supply systems as well. In the long run, the impact on the budget may be more negative.

$\checkmark$ Effects on trade: emigration changes trade relationships too. Migration and foreign trade can be substitutes and supplements, so commercial effects of emigration are not clear.

\section{Summary}

As a summary, we can say that very few studies have been done on emigration so far in Hungary, so we thought we would prepare an overview study on this subject. The databases of our survey were known materials published since the change of regime (the change of regime in Hungary marks the era in which the Hungarian state became a democratic state quit with the one party regime and its cultural and ideological relations, and transformed peacefully into a democratic, republican European state. The change of regime is essentially linked to the year 1989, since the most important events occurred in this year regarding proclamation of the Republic of Hungary, death of János Kádár), based on which we found that emigration from Hungary in recent years has reached a certain level where it already has a great effect on economy.

Due to the nature of data sources it is easier to examine international migration in the host countries, and most of the literature focuses on the effect of migration in the host countries, too. We can find fewer writings about the effects of migration on the sending countries, especially on Central and Eastern European countries, although more and more analyses have been made about this topic over the last few years.

In our analysis, we are focusing on the possible causes, characteristics and consequences of emigration from Hungary, and our main focus is on the domestic labour market. Because of database problems mentioned before, the data we used in our paper come from the Labour Market Survey of Hungary.

Based on our calculations we found that about $3 \%$ of the Hungarian population are currently working abroad. According to our analysis, one of the main territorial units of emigration has been Budapest and its surroundings in recent years. Various demographic surveys show that most of the emigrants are men (53\% of those who are leaving the country), and they come from one or five to six-member households. Emigration from two or three-member households or single-parent families is negligible. Those who are living abroad are from younger (mostly single) and educated age groups. Based on data from 2016, the proportion of graduates in the United Kingdom is the highest among the target countries (36\%). Skilled workers leaving Hungary generally prefer Germany or Austria.

Doing our research, we did not take the number of those who study abroad into account (because of the lack of data), however, based on studies, it is likely that the majority of (Hungarian) students learning abroad are planning their life abroad.

According to the correlations of our research, the most effected migration layer is the layer of young people ( $75 \%$ of emigrants are under 40$)$, singles ( $64 \%$ of emigrants are not married), skilled workers and graduates.

Our opinion is that the emigration will continue until the wages in Hungary won't reach the the Western European levels. This is not easy to do because many companies has chosen Hungary because of the cheaper workforce and there is a risk that they will move their factories to other countries. Many people left Hungary because of better carrier options and also the benefits of the Western and Nordic welfare states are attractive. We can also notice that many children wouldn't born if their parents couldn't have extra social help in Great Britain for example. Some people also mention about the stable law system and the reliable political system which they face in their new homeland. Doing a research about this can be a next step for us. 


\section{References}

Blaskó Zs., Ligeti A. S. and Sik E. 2014. Magyarok külföldön - Mennyien? Kik? Hol?, In: Kolosi T. and Tóth I. Gy. (2014). Társadalmi Riport 2014., TÁRKI. Budapest. pp. 351-372. . Blaskó Zs. and Gödri I. 2016. A Magyarországról kivándorlók társadalmi és demográfiai összetétele. In. Blaskó Zs. - Fazekas K: Munkaerőpiaci Tükör 2015. MTA KRTI-KTI. Budapest 59-71. pp, Regionális Tudományi Kutatóközpont. Közgazdaság - Tudományi Intézet. Budapest. ISSN 1586-460X

Cseresnyés F. 2005. Migráció az ezredfordulón. ISBN 9789639123397. Nordex Kft. Dialog Campus Kiadó. Európai Uniós kiadvány

Dustmann, C. and Weiss Y. 2007. Return Migration: Theory and Empirical Evidence from the UK. DOI: 10.1111/j.1467-8543.2007.00613.x British Journal of Industrial Relations, 45 (20), pp. 236-256.

Galgóczi, B., Leschke, J. and Watt, A. 2012. EU Labour Migration in Troubled Times. Skills Mismatch, Return and Policy Responses, ETUI book

Hárs Á. 2016. Elvándorlás és bevándorlás Magyarországon a rendszerváltás után nemzetközi összehasonlításban. In: Blaskó Zs. - Fazekas K.: Munkaeröpiaci Tükör 2015. MTA KRTI-KTI. Budapest. pp. 39-53.

Hárs Á. and Simon D. 2015. A munkaerő-migráció változása a kétezres években Magyarországon. In Budapesti Munkagazdasági Füzetek BWP - 2015/². MTA KRTK, Budapest

KSH 2016. Magyarország, 2015. 4/10349. ISSN 1416-2768. Budapest.

KSH 2018. Migráció. [online] http://demografia.hu/hu/migracio [accessed 01.28.2018]

KSH 2017. Magyarország munkanélkülisége. [online] https://www.ksh.hu/munkanelkuli seg [accessed 06.06.2017]

Layard, R., Blanchard, O., Dornbusch, R. and Krugman P. 1992. East-West Migration. The Alternatives. The MIT Press Cambrige. Massachusetts.

M. Pakurár, B. Cehla, J. Oláh and A. Nábrádi 2013. Employment characteristics of Ukrainian citizens in Hungary. APSTRACT Applied Studies in Agribusiness and Commerce. Agroinform Publishing House, Budapest, 7, (4-5), pp. 113-120.

Oláh, J., Halasi, G., Szakály, Z., Popp, J. and Balogh, P. 2017. The Impact of International Migration on the Labor Market - A Case Study from Hungary. Amfiteatru Economic, 19(46), pp. 790-805.

Sik E. and Szeitl B. 2016. Polgárság a mai Magyarországon. Szerk.: Kolosi Tamás - Tóth István György.. TÁRKI: Budapest, ISSN 1216-6561

OECD 2011. OECD International Migration Database. [online] https://stats.oecd.org/Index.aspx?DataSetCode=MIG [accessed 30.06.2017]

Paul Collier 2016. Exodus - How Migration is Changing Our World, Oxford University Press

\section{Bio-note}

Margit Csipkés (Phd) is senior lecturer at the University of Debrecen Faculty of Economics and Business Institute. Her research interest is connected to the EU's most important fields like energy, migration and funds. She is publishing about linear programming and use of statistical methods too.

Sándor Nagy is assistant lecturer at the University of Debrecen. His research fields cover the international and European affairs which are affecting the national politics of the EU member states. He is organizing problem solving simulation games about the EU and UN for the students of UD. 